\title{
The Implementation of Cooperative Learning in the Engineering English through Contextual Learning
}

\author{
Ayuddin $^{\mathrm{a}, 1}$, R. Husnan ${ }^{\mathrm{a}, 2}$ \\ Civil Engineering Department \\ ${ }^{a}$ Gorontalo State University, Gorontalo, INDONESIA \\ ${ }^{1}$ ayuddin_ung@ rocketmail.com, ${ }^{2}$ rawiyah@ung.ac.id
}

\begin{abstract}
The Engineering English is a learning material that is relatively difficult to understand by students. However, it can be more fun and easily understood by the student if the learning process is processed properly or find the right method. The Engineering English educators need to continue to explore the techniques of new pedagogical methods to inform and expand a student thinking in the classroom. The method that considered to achieve the goal of learning is contextual learning. The Contextual learning is intended to be more cooperative nature of the material presented by the educator. The purpose of the implementation of cooperative learning through contextual learning is to create opportunities for constructing and exploring insight learning, not only receive a knowledge. This method offers the techniques for Engineering English educators to produce students who are more creative, critical thinking, and to develop an extensive knowledge. This paper provides an overview of contextual learning and how to plan interventions to student learning result.
\end{abstract}

Index Terms - contextual learning, intervention plan, engineering english.

\section{Introduction}

English which is taught in the department of civil engineering at the Gorontalo State University previously is general english, as well as the English which is taught in language faculty. We consider as a researcher that the English in the civil engineering department should be directed to the English which more oriented to engineering English. Engineering english given for students is more useful than the general english which studied in the language because engineering english is more related to the industry, meaning that when students put through to the practice of foreign companies in particular industries, they will be familiar with the terms of engineering language. However, it's not only the terms of engineering that must be understood, but it is also the techniques that lead to the deeper problem of engineering. Therefore that is our challenge that faced today in english subject in the department of civil engineering at UNG, then the authors took the initiative to change the characteristic of both the conventional learning methods and the content of the subject that being taught with more general english.

Realization the concept of contextual learning in the classroom is determined by a control from professional lecturer and management of learning materials in the classroom. Lecturer is the source of the achievement of the mission of educational reform, they are in a central point for managing, directing and creating an atmosphere of teaching and learning activities to achieve the goals that lead to quality education. Therefore, lecturer required to be more professional, innovative, perspective, and proactive in the classroom.

Human resources are developing, then the world of education need to create a learning environment which accordance with the mindset of students. Learning will be meaningful if the students "experience" what they learned, not just know about it. Therefore, through contextual learning in the subjects of engineering english, mastery of the target is expected to be more successful and the students can be as much as possible to develop their competence.

Contextual learning approach is the concept of learning that help a lecturer make a connection between the learning material to the real world situations and encourage students to make connections between the knowledge and its application in daily life. With this concept, the learning outcomes expected to be more meaningful for students. The learning process occurred naturally in the form of student activities and work experience, instead of transferring knowledge from lecturer to students. Contextual learning which conducted is an educational process that is holistic and aims to motivate students to understand the meaning of the subject matter learned by relating the material to the context of their daily lives so that students have the flexible engineering english skills that can be applied in industry and society extensively.

Many benefits for students in the implementation of contextual learning in the classrooms. For example, the students will be active participants not just passive observers, and they will be more responsible with the subject which they learned. Learning will be more meaningful and enjoyable. Students will work hard to achieve the goals of learning, they use their experience and prior knowledge to construct new knowledge. The application of this concept is not contextual lecturer, but the lecturer listen more the students in thought or students express an idea or ideas is held by students so that the students are more active learning and create a more conducive learning atmosphere. Also encourage students to better 
understand the nature, meaning, and the benefits of learning, enabling them to be diligent, and motivated to keep learning, even though engineering English is more frightening and are considered relatively difficult for students.

\section{Theory of Contextual Learning}

\section{A. Definition of Learning}

Learning is essentially a process of interaction in all the situation that surrounding an individual. Learning can be considered as a goal-directed process and the process done through a variety of experiences. Learning is also a process to see, observe and understand something (Sudjana, 1989: 28).

Learning activities focusing on "how student learning" rather than on "what students learn". Learning more emphasis on how to achieve that goal. Based on this definition, the things that cannot be forgotten is to achieve the goal of learning; how to organize, how to deliver learning content, and how to organize the interaction between learning resources that exist, in order to function optimally so that the learning process will be conducted based on our learning purposes.

Learning activities carried out by two actors, the lecturer and students. Lecturer is teaching behavior and student behavior is learned. Teaching behavior and learning behavior are related to the learning materials. In the learning process, there are several interacting components as a single unit. The components of the learning process in general include: a) the purpose of teaching and learning; b) the content of learning materials; c) Methods of teaching and learning; d) media learning; e) Evaluation of learning outcomes; f) Learners; g) Lecturer. Each lecturers or students must master these components and skilled in applying the learning process so as to produce a quality teaching and learning process.

The Engineering english in substance is a series of learning activities undertaken by lecturer optimally so the students are taught about a particular matter do good teaching and learning activities. In other words, Engineering english is the effort made by the lecturers in creating certain materials conducive learning to achieving the goal of engineering english learning.

\section{B. Principles of Engineering English Learning}

The principle of learning by Scarino, Vale and Clark said that there are at least eight principles of language learning in general;

- $\quad$ Learning to learn optimally when they are needed as individuals with needs and their interests.

- Learning to learn optimally when they are needed the opportunity to actively use the target language to communicate with a variety of learning activities.

- Learning to learn optimally when they are much activated by the target language which is used in the process of communicating, both verbally and in writing the capabilities, needs, and interests.

- Learning to learn optimally when they are exposed to different aspects of verbal structure of the target language and examines the cultural meanings contained in the target language.

- Learning to learn optimally when they are shown on the cultural aspects of native speakers of the target language and direct experience in the target language culture.

- Learning to learn optimally when they realize the role of the nature of language and culture.

- Learning to learn optimally when they are given effective feedback about the progress of their learning on an ongoing basis.

- Learning to learn optimally when they are given the opportunity to manage their own learning.

\section{Contextual Learning}

Contextual learning is a concept of learning that can help a lecturer to harmonize the learning materials with the real world situation and motivate students to make connections between knowledge and its application in their lives as family members, citizens, and workers. Contextual learning enables students to connect academic content of the materials with the context of everyday life to find meaning. Contextual learning expands personal context further by giving students a fresh experience that will stimulate the brain to establish new connections to find a new meaning (Johnson, 2002).

Contextual learning is a system that stimulates the brain to develop patterns that embody meaning. Contextual learning is a teaching system that matches the brain that results in the context of academic content with the daily life of students.

Contextual learning is said to be a comprehensive system, as it consists of contextual learning the parts are connected to each other, if these parts intertwined with each other, then the effect will be produced better results. In contextual learning allows the five forms of learning are important, namely:

- $\quad$ Relating

Relating is the most powerful strategy and the core of constructivism. Lecturers use this strategy when they linked the new concept with something that is already known by the student. So therefore, it relate what is already known to the student with new information.

- Experiencing

Experiencing is at the core of learning in which the contextual linking means linking new information with prior knowledge and experience. Learning can be more quickly when students can manipulate equipment and materials as well as do other forms of active research. Motivating.

- Applying

In the applying means applying a concept of a student when he was doing problem-solving activities. Teachers can motivate students by providing realistic and relevant training.

- Cooperating

Students work individually often does not help significant progress. Conversely, students who work in groups are often able to resolve complex problems with minimal assistance. The experience of 
cooperation not only helps students know teaching materials, but consistent with the real world.

- Transferring

It is the role of the teacher to make a variety of learning experiences with a focus on understanding rather than by rote.

\section{Contextual Learning System}

Contextual learning system is an educational process that aims to help students see the meaning of the academic material that they learn by connecting with the academic subjects in the context of their everyday life, namely the state of the context of personal, social, and cultural. To achieve this goal, the system includes eight components. Eight contextual learning system include:

- Make meaningful linkages

- Doing meaningful work

- Conduct a self-regulated learning

- Cooperate

- Critical thinking and creative

- Helping individuals to grow and develop

- Achieving a high standard

- Conducting authentic assessment.

\section{Methods}

The research method is the operational and scientific steps that conducted by researchers to find someone who responsible for the formulation of research problems that have been made. The research method is a way of solving problems in a planned and carefully carried out with the intention of getting the facts and conclusions in order to understand, explain, predict, and control the situation. The approach and the type of research that used in this paper is qualitative approach and research. Qualitative research is a research procedure that produces descriptive data of the observed behavior. So the research is done by means of analysis, depicting or describing facts. The study is descriptive in accordance with the observed picture of the situation illustrates how the learning process of engineering english with a contextual approach. In the data collection is done by three methods, namely by using observation, interviews, and documentation.

\section{Results and Discussion}

The subjects of engineering english is a subjects that avoided by students because of this subjects requires a lot of memorization of vocabulary so that they can not understand the material being taught when learning. The phenomenon that occurs when these subjects will be taught is more student prefer not to attend to this course and the students who attend they do not be active and just sit without motivation so they can not understand the explanation from the lecturer. English is taught namely engineering english that related to hydraulics, transportation, project management, and construction of building. All contents materials are provided only related with the engineering. The goal is to make students practice when they are able to understand english related engineering, or when the students has completed the study, the subjects of the engineering english ever taught can be applied in the industrial world.

The learning model is applied earlier in the civil engineering department at the State University of Gorontalo to the subjects of english is the general english that does not related with the engineering science particularly civil engineering such as hydraulics, transportation system, construction, and project management and learning model that is given to students still using conventional model.

Conventional learning model is a learning model that does not think of the model of interaction between students and students, and between lecturers and students, as a result of students becoming uncomfortable in learning, boring, and tiring in the activities of the learning process. This is due to the absence of variation in learning activities. The method is often used in conventional learning model is the lecture method. Lecture method is narrative verbally by the lecturer in class. In the implementation the students just listen to the lecturer carefully and noted the important subject material content presented by the lecturer. Thus, the main activities are lecturer will explain and students listen to or record what is presented by the lecturer.

The students only receive what is presented by the lecturer, as well as student activities for expression is very less, so that the students become passive in learning, and students learn less meaningful as more memorizing. Students must follow the way of learning that is selected by the lecturer, they must studying the sequence defined lecturer, and don't have an opportunity to express their opinion. In addition, the lecturers rarely teach students to analyze in depth about a concept and rarely encourage students to use higher logical reasoning such as the ability to prove or demonstrate a concept. This incident makes me as a writer tend to create a more comfortable learning atmosphere and be interactive, ie the use of the concept of contextual learning. In addition, the material is related to the engineering english. The good things in contextual learning that it is done to be more meaningful and real. This means that students are required to be able to capture the relationship between on-campus learning experience with real life. This is very important, because the material can be found to correlate with real life, not only for the material that will serve functionally, but the material will be studied closely embedded in the memory of the student, so it will not be easily forgotten. Another advantage is learning 
more productive and able to foster the strengthening of the concept of the student as a model of contextual learning follow the flow of constructivism, in which a student is led to discover his own knowledge. Through the philosophical basis of constructivism can experience the students are expected to learn not memorize.

In the engineering english learning experience through contextual learning to students in civil engineering departement, State University of Gorontalo. The classroom atmosphere become more comfortable and learning run smoothly because it is formed by the model by forming discussion groups are heterogeneous. Heterogan group formation is done so that lower level students will be assisted by the students in high level. The division of this group also aims to allow students to share information, discuss and work together in a group so that students can easily follow the lesson. this is in accordance with the opinion of Sanjaya (2009: 267) said that the concept of the learning community in contextual learning suggests that learning results obtained through cooperation with others, and supported by Vygotsky's theory of the group learning model is the emphasis of learning as a process of interactive dialogue. With this sharing model group, it is visible from any member of the group who had to adapt to the group members so that each group can work well together and help each other in solving problems given by the lecturer.

Then next is constructivism is the process of building or construct new knowledge in cognitive structure based on the student learning experience that occurs during the learning process takes place. In this process, students are asked to construct their own knowledge with the help of a facilitator so that the student may find this of construction of new knowledge. Although the process has not been popular students construct their own knowledge with the teacher centered learning that puts students as learning object who receiving information passively, but with this model turns out students feel more comfortable and confident in constructing their own knowledge. Therefore, as a lecturer, we emphasize that learning English is not a technique that is associated with mere memorization process but the process of constructing knowledge in accordance with the learning experiences they have. Furthermore, students are trained to find the idea of science being taught. The learning process is based on the search and discovery through the process of thinking systematically. At this stage the student is still difficult to adjust to this stage, it is because the student is familiar with the conventional learning which place students as passive objects who only receive knowledge from lecturer directly without discovery itself. However, the contextual model of learning do students have started to realize this would be an obvious problem and want to solve, so students are encouraged to find their own resolution of the problem. In terms to provide feedback or comments between groups are very active and fun discussion occurred between the groups with each other. Furthermore, the reflection stage, students write their conclusions and learning experiences during the learning process that conducted with the model of contextual learning. Basically all the students who formed the group said that the method of contextual learning more fun and better understand the content of the subject matter presented by the lecturer so that a recommendation for this method can be maintained for English courses in the department of civil engineering techniques. From the results it was found that contextual learning increased significantly from academic learning outcomes produced by students when compared with the conventional method is $92.36 \%$. This acquisition is greater than $85 \%$ when compared to the previous cycle which only reached $58.54 \%$. The academic achievement of learning outcomes in the application of contextual learning because students are more active, interactive, and have a better understanding of the material taught.

\section{Conclusion}

From various considerations and empirical evidence indicates that contextual learning model is very appropriate to be applied on engineering english in the department of civil engineering in order to improve student learning outcomes. Based on the test results of the application of contextual learning model was superior in many ways when compared to conventional learning, such as: a) the achievement of higher academic learning outcomes; b) more productive and capable students to develop concepts for the flow of constructivism c) Learning is more meaningful and real as it can understand the relationship between learning experiences on campus with real life d) is more conducive to improving relationships between students and lectures.

The advantages of contextual learning model is not just focused on what was taught by lecturers but rather on understanding and deepening of the lesson content that involves interaction with other students and connect the subject matter with the reality on the field. Learning more productive and innovative so as to encourage students toward active learning and contextual learning through student actually experienced students and find out for yourself what is learned as a result of its reconstruction.

\section{Acknowledgment}

The author would like to thank for department of civil engineering, faculty of Engineering, Gorontalo State University for conducting the research. Lastly, the author would also like to thanks the UPI's International Conference on TVET for this publication. 


\section{References}

[1] Berns, R. G. \& Erikson, P, "Contextual teaching and learning". The Higlight Zone: Research @ Work No . 5. The National Centers for Career and Technical Education, USA, 2001.

[2] Blanchard, A, "Contextual teaching and learning". Educational services, Horizons Electronic Lesson Plans Resources, 2001.

[3] Borko, H., \& Putnam, R. T, "The role of context in teacher learning and teacher education". In Contextual teaching and learning: Preparing teachers to enhance student success in the workplace and beyond, (pp. 34-67). Columbus, OH: ERIC Clearinghouse on Adult, Career and Vocational Education, 2000.

[4] Brookfield, S. D, "Transformative learning as ideology critique". In J. M. a. Associates (Ed.), Learning as transformation: critical perspectives on a theory in progress. San Francisco: Jossey-Bass Inc, 2000.

[5] Frazee, B. .Questioning, "A Web-based System for the Professional Development of Teachers in Contextual Teaching and Learning Project”. Bowling Green, OH: Bowling Green State University, 2001.

[6] Holubec, E, "Cooperative Learning". A Webbased System for the Professional Development of Teachers in Contextual Teaching and Learning Project. Bowling Green, OH: Bowling Green State University, 2001.

[7] Johnson, Elaine B, "Contextual Teaching and Learning". Thousand Oaks, California: Corwin Press, Inc. Yogyakarta: Gajah Mada University Press, 2002.

[8] Joyce, B. \& Weil, M, "Models of Teaching". 5th Edition. Boston : Allyn \& Bacon, 1996.

[9] Kolb, D. A, "Experiential learning: Experience as the source of learning and development". Englewood: Prentice Hall, 1985.

[10] Moffitt, M, "Problem-based Learning". A Webbased System for the Professional Development of Teachers in Contextual Teaching and Learning Project. Bowling Green, OH: Bowling Green State University, 2001.

[11] Petrina, S, "Curriculum change in technology education: A theoretical perspective on personal relevance curriculum designs". Journal of Technology Education, 3(2), 37-47, 1992.

[12] Pierce, J. W., \& Jones, B. F, "Problem-based learning" Learning and teaching in the context of problems. In Contextual teaching and learning: Preparing teachers to enhance student success in the workplace and beyond (pp. 69-95). Columbus, OH: ERIC Clearinghouse on Adult, Career and Vocational Education, 2000.

[13] Sanjaya, Wina, "Strategi Pembelajaran Berorientasi Standar Proses Pendidikan". Bandung: San Grafika, 2006.

[14] Scarino, A., Vale, D., McKay, P. \& Wichmann, K, “All Inservice Facilitators' Handbook: A Professional Development Course for Language Teachers". Curriculum Corporation of Australia. Melbourne, 1991.

[15] Sears, S. J., \& Hersh, S, "An overview of the project". In Contextual Teaching and Learning: Preparing Teachers to Enhance Student Success in the Workplace and Beyond, pp. 1-16). Columbus, OH: ERIC Clearinghouse for Teaching and Teacher Education. (ERIC Document Reproduction No. ED427 263), 1998.

[16] Souders, J, "Contextually based learning: Fad or proven practice". American Youth Policy Forum, Washington DC, 1999.
[17] Sudjana, S “Metode dan Teknik Pembelajaran Partisipatif". Bandung: Fallah Production, 2001.

[18] Sudjana, N, "Penilaian Hasil Proses Belajar Mengajar". Bandung : PT Remaja Rosda Karya, 2004.

[19] Tennyson, R. D, "An educational learning theory for instructional design”. Educational Technology, 32(1), 36-41, 1992.

[20] Wankat, P. C, "Improving engineering and technology education by applying what is known about how people learn". Journal of SMET Education, 3(1\&2), 3-8, 2002.

[21] Yang, J. C. \& Lin, Y. L, "Development and evaluation of an interactive mobile learning environment with shared display groupware". Educational Technology \& Society, 13(1), 195-207, 2010. 